ఠ

\title{
Profile of eliglustat tartrate in the management of Gaucher disease [Corrigendum]
}

Sechi A, Dardis A, Bembi B. Ther Clin Risk Manag. 2016;

$12: 53-58$.

On page 57, left column, line 22, the text "patients who result in poor metabolizers should not be treated with this drug" should have been "patients who result in CYP2D6 ultra-rapid metabolizers or who are indeterminate metabolizers should not be treated with this drug".

Therapeutics and Clinical Risk Management is an international, peerreviewed journal of clinical therapeutics and risk management, focusing on concise rapid reporting of clinical studies in all therapeutic areas, outcomes, safety, and programs for the effective, safe, and sustained use of medicines. This journal is indexed on PubMed Central, CAS,
EMBase, Scopus and the Elsevier Bibliographic databases. The manuscript management system is completely online and includes a very quick and fair peer-review system, which is all easy to use. Visit http://www.dovepress.com/testimonials.php to read real quotes from published authors. 